\title{
The Effects of Formative and Dynamic Assessments of Reading Comprehensions on Intermediate EFL Learners' Test Anxiety
}

\author{
Seyyed Hossein Sanaeifar \\ English Language Department, Qaemshahr Branch, Islamic Azad University, Qaemshahr, Iran \\ Fatemeh Nafarzadeh Nafari \\ English Language Department, Qaemshahr Branch, Islamic Azad University, Qaemshahr, Iran
}

\begin{abstract}
The aim of this study was to investigate the effects of formative and dynamic assessments of reading comprehension on intermediate EFL learners' test anxiety. To conduct the study, 50 out of 66 intermediate Iranian EFL learners, males $(\mathrm{N}=22)$ and females $(\mathrm{N}=28)$ with age range of 14 to 19 were selected from a private institute based on their performance on the Oxford Placement Test (syndicate, 2001). They were randomly classified into formative and dynamic assessment groups of intermediate EFL learners which were 25 learners in each group. For the formative group the researchers administered reading comprehension test after teaching each reading task. The researcher provides feedback for each student based on their performance on the test separately. For dynamic group the researcher used sandwich model of dynamic assessment i.e. after each reading task the researcher administered reading comprehension test as a pre-test then after collecting pre-test information, the researcher provided mediation and necessary information for answering test question generally to students. The data were collected through the pre-test and the post-test. For pre-test and post-test the researcher used test anxiety questionnaire (Sarason, 1984). The data were analyzed using SPSS software. The result of this study showed that formative assessment of reading comprehension have statistically significant effect on intermediate EFL learners' test anxiety reduction and dynamic assessment of reading comprehension have statistically significant effect on intermediate EFL learners' test anxiety reduction. Also dynamic assessment of reading comprehension had more effect on intermediate EFL learners' test anxiety reduction.
\end{abstract}

Index Terms — formative assessment, dynamic assessment, reading comprehension, test anxiety, EFL learner

\section{INTRODUCTION}

One of the important aspects of English language teaching and learning is the language assessments, as the future of students and language learners are at stake by the decisions made on the results of these assessments. Designing proper and useful assessment is vital for gaining high degrees of language achievement. There are two types of newly developing assessment in recent years which are formative and dynamic assessments. Formative assessment is a kind of classroom-based assessment which is concern with the language content and lesson objectives. Formative assessment determines whether a learner was success or not to achieve objective of a language program. It reflects the learners' abilities to master the material covered during instruction. But dynamic assessment goes beyond diagnostic role of testing in language teaching. Dynamic assessment concern with the learner's performance with assistance from teacher and the extent to which the learner can benefit from this assistance not only in completing the task, but in transferring this mediated performance to different tasks (Poehner \& Lantolf, 2005).

On the other hand, reading is one of the most useful skills, especially in EFL contexts where access to foreign language is mainly rely on written language. Studies have shown that reading is an important source of input and it is also can be an anxiety provoking activity (Saito, Horwitz, \& Garza, 1999). Test anxiety is an apprehension over evaluation and assessments. It is a fear of failing in test and conscious or unconscious stressful and fearsome experience by learners about tests. Anxiety about failure in the test or sense of unaccountability to response the test items can block reading comprehension process $(\mathrm{Na}, 2007)$. Unfamiliar words, writing system and cultural material can increase learners' anxiety and fear about reading comprehension tests. Generally speaking any kinds of anxiety potentially affect language teaching and testing.

In Iran EFL context static assessment in teaching and testing is dominant tool for evaluating learner language achievement and knowledge. Also in static assessment types they rely on summative assessment more than formative type of assessment. The focus of current trend of testing in Iran is on language product rather than language process. By using dynamic assessment principles in classroom, language process is considered too. In addition Iranian EFL learners commonly experience high level of anxiety in their assessment especially in high stake tests like university entrance test. Such an anxiety can decrease learners' motivation toward learning language. Moreover reading comprehension is the 
other troublesome issue in Iranian English language learning context. Learners frequently show low level of reading comprehension potency in their language tests. So regarding above mentioned problems, the researcher wants to investigate the effects of formative and dynamic assessments of reading comprehension on intermediate EFL learners' test anxiety. The current study tried to answer the following questions:

Q1-Does formative assessment of reading comprehension have any statistically significant effect on intermediate EFL learners' test anxiety reduction?

Q2-Does dynamic assessment of reading comprehension have any statistically significant effect on intermediate EFL learners' test anxiety reduction?

Q3-What type of reading comprehensions' assessment has more effect on intermediate EFL learners' test anxiety reduction?

\section{REVIEW OF THE RELATED LITERATURE}

\section{A. Theoretical Background}

Until very recently static assessments dominantly used for evaluating and assessing learners specific language abilities. By using this kind of assessment learners' educational decisions are made based on the current status of the learners' abilities and learners' future predicted accordingly. Formative kind of assessments is static one too but it is administered frequently before completion of an instruction. As Bachman (1990) points out, formative assessment has a much closer view to instruction because it results gives more feedbacks into classroom teaching process rather than summative assessment. Although formative assessment can be beneficent in language learning, there are some concerns over their effectiveness in improving learning. Effective formative assessment in language teaching and assessment, must be based on integrated and harmonized practices. Formative assessment designed to determine whether a learner was on track of the objectives of language programs or not. Formative assessment shows students' standing place during the instructional programs and reflects the learners' abilities of mastering the material presented during the instructional period in the program.

Brown (2004) argued that effective formative assessment towards subsequent classrooms' instruction can show high level of consequential validity. The term formative assessment refers to procedures adopted in classrooms at different periods of time along a course of instruction aimed to providing the teacher and students with feedback of their success or failure in educational program (Bachman, 1990; Fulcher \& Davidson, 2007). Formative assessment provides the necessary information for adjusting teaching and learning at the time they are happening. In this sense, formative assessment informs teacher or instructor about students' level of knowledge that achieved at a point of timely adjustments occur. These adjustments can help teacher or instructor to ensure students achieve targeted learning goals within a course program. Poehner and Lantolf (2005) criticized this view and argued that in formative assessment, assessment and instruction remain two separate parts. Also according to Torrance and Pryor (1998) the linkage between assessment and learning is vague for teachers and there is no actual intervention in the process of the learners' development in formative assessment practices in classroom level.

Ellis (2003) argued there are two major types of formative assessment including planned and incidental formative assessments. The planned formative assessment directly evaluates learners' language knowledge or ability to perform tasks and uses a rating scale to measure learners' achievements. The incidental formative assessments occur through the instructional conversations between teachers and students during classroom practices. In addition he distinguishes two types of incidental formative assessment including internal and external incidental formative assessments. Internal one occurs when teacher asks questions and provides immediate feedback for learners' performance. On the other hand, the external incidental formative assessment is based on teacher and students reflection on learner performance either while in doing tasks or after completing them (Ellis, 2003). Consequently, Stenberg and Grigorenko (2002) believed to a paradigm shift in the formative assessment practices to integrate instruction and assessment as a unified activity i.e. dynamic assessment practices.

It is very obvious that such a decision or prediction cannot be very fair and valid because human kind are in constant changing process all the time. Unlike static approaches to assessment, dynamic assessment seeks to instruction during the assessment itself and signifies the pedagogical function of assessment in providing opportunities for learning. Recently the introduction of dynamic assessment is seen as a response against static tests shortcoming which measure the learner's current knowledge (Poehner, 2008). Dynamic Assessment is originated from the theory of Vygotsky's social constructivism which is named as socio-cultural perspective. Child's learning takes place through presenting and participating in sociocultural experiences with a more experienced adult or more knowledge educator (Poehner \& Lantolf, 2005). The dynamic assessment concern with learning process so it is highly interactive and process-oriented assessment.

Lidz (1991) defines dynamic assessment as an approach that follows a test-intervene-retest format and that focuses on learner modifiability and based on producing interventions by more knowledgeable individuals toward improving learners' performance. Poehner (2008) defines dynamic assessment as an active collaboration with learners which simultaneously shows their current abilities and promotes their potential future development. In classroom level dynamic assessment means as an understanding of learners' abilities supporting by instruction aims to promoting learner abilities to next level of knowledge. Feuerstein, Rand and Rynders (1988) emphasized the mediated interaction 
between the learner and the environment, claims that in mediation learning should be implied into the process of teaching. Dynamic assessment is process-oriented assessment and goes beyond the cognitive measure of the one-shot and product-oriented standardized test. The dynamic assessor instructs learners on how to complete tasks and activities, provides mediated assistance on how to master them, and evaluates their progress in learning to solve similar problems in future without mediation (Kirschenbaum, 1998).

Dynamic assessment included intentionality, reciprocity and transcendence components. Intentionality component of dynamic assessment refers to the process of mediation in which the mediator achieves in-depth insight of a learner's potential abilities. The mediator is also able to enhance learners' development by teaching simultaneously with testing (Poehner, 2008). Reciprocity component is refers to the learners' response to the instructors' mediation. Changing the learners' behaviors due to mediation allows the mediator to measure the amount and quality of intervention needed to produce potential development of learners' performance in absence of mediation. Feuerstein (2002) indicated that reciprocity focusses on the triangular relationship between the mediator, the learner and the obtained information through mediation process. Transcendence is concerns with the widening of interaction between mediator and learners beyond current point of abilities towards future potential point of learners' development (Feuerstein, 2002). Transcendence is the hurt of the mediated learning and cognitive development depend on achieving this component.

Lantolf and Poehner (2008) mentioned there are two major approaches to dynamic assessment including interactionist and interventionist approaches in which consisted of three phases: pre-test, mediation, and post-test. Poehner (2008) maintains that interactionist dynamic assessment follows Vygotsky's cooperative interaction notion. In such an approach to dynamic assessment, the interaction between mediator and learner has collaborative essence which is very sensitive to the learners' zone of proximal development. During an interactionist dynamic assessment, mediators' questions, hints or prompts are not pre-planned; instead, they emerged from mediated interaction between the mediator and the learners. The mediator responds to the learners' needs and continually re-adjusts the mediation process. The interventionist dynamic assessment is formal and standardized approach, concerned with psychometric properties of test procedures (Lantolf \& Poehner, 2008). As Poehner (2008) believes during an interventionist approach, teachers follow an approach to mediation in which all prompts, hints, and leading questions have been pre-planned and arranged in a hierarchical steps. Poehner (2008) states that the distinctive feature of interventionist dynamic assessment is the use of standardized procedures and mediation in order to produce quantifiable results.

Two main models of dynamic assessment are sandwich and layer cake models. The sandwich model consists of three phases: pre-test, mediation and post-test. At first phase, learners are asked to do pre-test tasks or activities; then at second phase, they are exposed to mediation by teacher or mediator and at final phase they complete post-test tasks or activities. In the sandwich format the instruction is given between the pre-test and the post-test. The performance on the post-test is compared to the pre-test in order to determine a learners' performance progress due to the mediation. In the layer cake format mediation is given during the test administration, whenever a problem or misunderstanding occurs. In this model, learners are given a test item by item. If they answer the first item correctly, then allowed to do the second item. The assistance or mediation are graded, like layers of a cake. Methodological aspects of dynamic assessment received some criticisms. Standardization and validation of dynamic assessment have been critically questioned by some specialists (Guthke, Beckmann \& Dobat, 1997). Modifiability which is the essence of dynamic assessment challenged by critics and viewed as source of threat to the test reliability. Indeed, the modifiability comprise changing of the learner's performance during assessment; on the other hand, the reliability is under threat (Bachman, 1990).

Reading comprehension takes place when cognition of words and phrases, immediate memory, background memories based on the readers' earlier experiences, interest in the reading topic and intelligence to understand of text work together appropriately. Successful reading is depend on comprehension and interpretation of texts' meaning. Many factors such as attitudes, motives, interests, curiosity, anxiety, classroom atmosphere, background knowledge, and emotional statues of learners can affect reading comprehension. Reading viewed as the most important academic language skill because reading is the basic tool for learning new information. Reading comprehension needs to get the main idea of text, to search specific information, to learn new information, to synthesize and evaluate information from texts, for general comprehension and for pleasure (Grabe \& Stoller, 2001). Sellers (2000) believed that the nature of reading is complex skill because reading process comprised integration of learners' attention, perception, memory, and comprehension.

The three components of language anxiety are communication apprehension, tests anxiety, and fear of negative evaluation (Horwitz, Horwitz \& Cope, 1986). Sarason (1972) defined test anxiety as a tendency to drive out selfcentered, interfering responses when individuals deal with testing conditions. Zeidner (1998) defined test anxiety as a phenomenological, physiological, and behavioral reaction accompany with negative consequences and failure on testing situation. Hancock (2001) defined test anxiety as a disturbing emotional phenomenon that has physiological and behavioral aspects, and that is experienced in testing or evaluation situations. Test anxiety has cognitive, social, emotional and physiological manifestation. Students' poor performance in the previous tests can potentially make them anxious so they develop a negative feeling about tests and have destructive perceptions in evaluative situations. Anxious language students are often not able to show their complete performance for a test because they forget lesson points which they studied before due to test anxiety (Hancock, 2001). Students with higher amount of test anxiety show much poor performance in their tests and evaluative situations rather than their peers with lower amount of test anxiety 
(Cassady \& Johnson, 2002). Test anxiety is related to students' characteristics and emotional status and appears when students exposed to high important tests frequently in which success or failure in test, highly emphasized for them.

\section{B. Related Studies}

Poehner (2008) conducted a series of extensive dynamic assessment case studies examining oral proficiency among advanced undergraduate learners of French. The study showed that due to the mediation learners' oral proficiency improved. In an experimental study, Tzuriel and Shamir (2007) dynamically mediated students' basic communication skills. The study showed that the learners in the experimental group showed higher improvement in their communicative skill than those in the control group. Hessamy and Ghaderi (2014) studied the impact of dynamic assessment on the vocabulary learning of EFL learners. The result of the study showed that using dynamic assessment as a supplementary procedure positively improved both test performance and vocabulary learning of learners. Chen (2007) investigated the relationship between test anxiety and reading anxiety on Taiwanese college students' performance in reading. Findings revealed a high correlation between test anxiety and reading anxiety. Shomoossi and Kassaian (2009) carried out a study to investigate the effect of test anxiety on listening and speaking. The results revealed that anxiety is an important factor in taking oral tests than in the listening comprehension tests.

\section{METHOD}

\section{A. Participants}

In this study 50 out of 66 intermediate Iranian EFL learners, males $(\mathrm{N}=22)$ and females $(\mathrm{N}=28)$ with age range of 14 to 19 were selected from a private institute in Sari, Mazandaran based on their performance on the Oxford Placement Test (OPT). Afterwards, they were randomly divided into formative assessment and dynamic assessment groups. The learners' experience in language learning was at least 2 years. A convenience sampling procedure was conducted for the subject selection.

\section{B. Instruments}

There were two instruments in this study. The first one was an Oxford Placement Test (Syndicate, 2001). This test was applied to homogenize language learners in the present study. It comprised 60 items in two parts. These parts designed for vocabulary/grammar (40 items) and reading comprehension (20 items). The second instrument was test anxiety questionnaire developed by Sarason (1984) and revised by Benson and Bandalos (1992). The questionnaire comprised of 20 items in a Likert scale format. The researcher piloted this questionnaire and calculated its reliability by using Cronbach alpha formula in which it was about 0.77 respectively.

\section{Procedure}

The data of this study collected through following procedure: at first an OPT test was administered among a subject pool of 66 of all participants 50 could meet the criteria. They were randomly classified into formative and dynamic assessment groups of intermediate EFL learners which were 25 learners in each group. Next for the purpose of evaluating their test anxiety level before the instructional phase, the test anxiety questionnaire was distributed among the participants as a pre-test. They were assured for confidentiality and ethical issues for the answer they provided. Then the instruction started for the two experimental groups. 5 reading task were selected from their course book (Top Notch 2) for instruction. Both groups' reading activities were taught in the same way. For the formative group the researcher administered reading comprehension test after teaching each reading task. The researcher provides feedback for each student based on their performance on the test separately. For dynamic group the researcher used sandwich model of dynamic assessment i.e. after each reading task the researcher administered reading comprehension test as a pre-test then after collecting pre-test information, the researcher provided mediation and necessary information for answering test question generally to students. Note that the researcher did not provide any feedback to them. Finally after mediation phase the researcher re-administered the test for students as a post-test. This process repeated for each reading comprehension task. The instructional phase last 16 sessions, each one and half hours two days a week for a period of two months. All groups exposed the same material and lessons with the same teacher (the researcher), however they were different in terms of type of assessment received. For the purpose of evaluating their test anxiety level after the instructional phase, the test anxiety questionnaire was distributed among the participants as a post-test. They were assured for confidentiality and ethical issues for the answer they provided. The data were collected during a period of two weeks. After collecting the data, they were analyzed using SPSS software.

\section{RESULTS AND DisCUSSION}

\section{A. Analyzing the First Research Question}

The descriptive statistics of the formative assessment pre and post-tests scores is showed in table 4.1 below. Table 4.1 shows that the mean of the formative assessment pre-test is more than the mean score of the post-test. It means that the level of test anxiety decreased (from 44.48 to 41.60 ). 
TABLE 4.1

DESCRIPTIVE STATISTICS OF THE FORMATIVE ASSESSMENT GROUP

\begin{tabular}{|l|l|l|l|l|l|l|}
\hline & $\mathrm{N}$ & Range & Minimum & Maximum & \multicolumn{2}{l|}{ Mean } \\
\cline { 2 - 8 } & Statistic & Statistic & Statistic & Statistic & Statistic & Std. Error \\
\hline FA pre & 25 & 51 & 23 & 74 & 44.48 & 3.046 \\
FA post & 25 & 46 & 24 & 70 & 41.60 & 2.838 \\
Valid N (listwise) & 25 & & & & & \\
\hline
\end{tabular}

Before testing this research question, it was necessary to see whether there is normality of the distribution of the pre and post-test scores. To do this, the researcher conducted a one-sample Kolmogorov-Smirnov test.

TABLE 4.2

ONE-SAMPLE KOLMOGOROV-SMIRNOV TEST OF NORMALITY

\begin{tabular}{|c|c|c|c|}
\hline & & FA pre & FA post \\
\hline \multirow{3}{*}{$\begin{array}{l}\text { N } \\
\text { Normal Parameters }\end{array}$} & & 25 & 25 \\
\hline & Mean & 44.48 & 41.60 \\
\hline & Std. Deviation & 15.229 & 14.192 \\
\hline \multirow{3}{*}{ Most Extreme Differences } & Absolute & .135 & .153 \\
\hline & Positive & .135 & .153 \\
\hline & Negative & -.081 & -.107 \\
\hline Kolmogorov-Smirnov Z & & .673 & .766 \\
\hline Asymp. Sig. (2-tailed) & & .756 & .601 \\
\hline
\end{tabular}

distribution is Normal.

b. Calculated from data.

As indicated in table $4.2, \mathrm{P}$ values were 0.756 and 0.601 respectively $(0.756>0.05,0.601>0.05)$, so the normality of scores distribution were confirmed. Therefore, parametric test was used for means comparison. To compare the pre and post-test means, the paired samples T-test was used. Inferential statistics of the formative assessment pre and posttest scores is shown in table 4.3 below.

TABLE 4.3

PAIRED SAMPLES T-TEST FOR THE FORMATIVE ASSESSMENT GROUP

\begin{tabular}{|c|c|c|c|c|}
\hline & & $\mathrm{t}$ & df & Sig. (2-tailed) \\
\hline Pair 1 & FA pre - FA post & 5.369 & 24 & .000 \\
\hline
\end{tabular}

According table 4.3 the paired samples $T$-test showed that $\mathrm{P}$ value was $(\mathrm{t}=5.369) 0.000<0.05$ therefore, it means that formative assessment of reading comprehension have statistically significant effect on intermediate EFL learners' test anxiety reduction.

\section{B. Analyzing the Second Research Question}

The descriptive statistics of the dynamic assessment pre and post-tests scores is showed in table 4.4 below. Table 4.4 shows that the mean of the dynamic assessment pre-test is more than the mean score of the post-test. It means that the level of test anxiety decreased (from 48.16 to 39.48 ).

TABLE 4.4

DESCRIPTIVE STATISTICS OF DYNAMIC ASSESSMENT GROUP

\begin{tabular}{|l|l|l|l|l|l|l|}
\hline & N & Range & Minimum & Maximum & Mean \\
\cline { 2 - 7 } & Statistic & Statistic & Statistic & Statistic & Statistic & Std. Error \\
\hline DA pre & 25 & 52 & 23 & 75 & 48.16 & 3.103 \\
DA post & 25 & 41 & 22 & 63 & 39.48 & 2.682 \\
Valid N (listwise) & 25 & & & & & \\
\hline
\end{tabular}

Before testing this research question, it was necessary to see whether there is normality of the distribution of the pre and post-test scores. To do this, the researcher conducted a one-sample Kolmogorov-Smirnov test.

TABLE 4.5

ONE-SAMPLE KOLMOGOROV-SMIRNOV TEST OF NORMALITY

\begin{tabular}{|ll|l|l|}
\hline \multicolumn{2}{|c|}{ ONE-SAMPLE KOLMOGOROV-SMIRNOV TEST OF NORMALITY } & DA pre & DA post \\
\hline N & & 25 & 25 \\
Normal Parameters & & \\
& & 48.16 & 39.48 \\
Most Extreme Differences & Mean & 15.515 & 13.411 \\
& Std. Deviation & .100 & .143 \\
& Absolute & .084 & .143 \\
& Positive & -.100 & -.097 \\
Kolmogorov-Smirnov Z & Negative & .498 & .714 \\
Asymp. Sig. (2-tailed) & & .966 & .688 \\
\hline
\end{tabular}

a. Test distribution is Normal.

b. Calculated from data. 
As indicated in table 4.5, P values were 0.966 and 0.688 respectively $(0.966>0.05,0.688>0.05)$, so the normality of scores distribution were confirmed. Therefore, parametric test was used for means comparison. To compare the pre and post-test means, the paired samples T-test was used. Inferential statistics of the dynamic assessment pre and posttest scores is shown in table 4.6 below.

TABLE 4.6

PAIRED SAMPLES T-TEST FOR THE DYNAMIC ASSESSMENT GROUP

\begin{tabular}{|c|c|c|c|c|}
\hline & & $\mathrm{t}$ & $\mathrm{df}$ & Sig. (2-tailed) \\
\hline Pair 1 & DA pre - DA post & 10.719 & 24 & .000 \\
\hline
\end{tabular}

According table 4.6 the paired samples T-test showed that $\mathrm{P}$ value was $(\mathrm{t}=10.719) 0.000<0.05$ therefore, it means that dynamic assessment of reading comprehension have statistically significant effect on intermediate EFL learners' test anxiety reduction.

\section{Analyzing the Third Research Question}

The descriptive statistics of both formative and dynamic assessments pre and post-tests scores is showed in table 4.7 below. Table 4.7 shows that the means of both formative and dynamic assessments pre-tests scores are more than the mean scores of the post-tests. It means that the level of test anxiety decreased in both cases (from 44.48 to 41.60 and 48.16 to 39.48 respectively).

TABLE 4.7

DESCRIPTIVE STATISTICS OF FORMATIVE AND DYNAMIC ASSESSMENTS GROUPS

\begin{tabular}{|c|c|c|c|c|c|c|}
\hline & $\mathrm{N}$ & Range & Minimum & Maximum & Mean & \\
\hline & Statistic & Statistic & Statistic & Statistic & Statistic & Std. Error \\
\hline $\begin{array}{l}\text { FA pre } \\
\text { FA post } \\
\text { DA pre } \\
\text { DA post } \\
\text { Valid N (listwise) }\end{array}$ & $\begin{array}{l}25 \\
25 \\
25 \\
25 \\
25\end{array}$ & $\begin{array}{l}51 \\
46 \\
52 \\
41\end{array}$ & $\begin{array}{l}23 \\
24 \\
23 \\
22\end{array}$ & $\begin{array}{l}74 \\
70 \\
75 \\
63\end{array}$ & $\begin{array}{l}44.48 \\
41.60 \\
48.16 \\
39.48\end{array}$ & $\begin{array}{l}3.046 \\
2.838 \\
3.103 \\
2.682\end{array}$ \\
\hline
\end{tabular}

According to table 4.7, fluctuation of dynamic assessments' means statistically more than fluctuation of formative assessments' means. As a result, dynamic assessment of reading comprehension had more effect on intermediate EFL learners' test anxiety reduction.

\section{Discussion}

As mentioned earlier, the current research tried to find out the effects of formative and dynamic assessments of reading comprehension on intermediate EFL learners' test anxiety. After analyzing the data, different findings have been taken. The first finding was that formative assessment of reading comprehension has statistically significant effect on intermediate EFL learners' test anxiety reduction. The second finding of this study was that dynamic assessment of reading comprehension has statistically significant effect on intermediate EFL learners' test anxiety reduction. The third finding of this study was that dynamic assessment of reading comprehension had more effect on intermediate EFL learners' test anxiety reduction.

One of the possible reasons for these finding could be that when the students exposed to formative and dynamic assessment, they assured about the teacher attention toward their performance and it could decrease their level of anxiety. Because dynamic assessment concerns with their future development and the meditation cooperative nature makes learners more confident than the formative group learners so dynamic assessment performed better in reduction of learners' test anxiety. Another possible reason was that frequent administration of reading comprehension tests at instructional period gradually improved the learners' feeling about exam and it could reduce their level of test anxiety.

This findings support Bachman (1990) points of view that argued formative assessment has a much closer view to instruction because it results gives more feedbacks into classroom teaching process rather than summative assessment. Although formative assessment can be beneficent in language learning. Also these findings were consistent with Feuerstein, Rand and Rynders (1988) point of view which emphasized the mediated interaction between the learner and the environment, claims that in mediation learning should be implied into the process of teaching. Also the findings of this study was confirmed Cassady \& Johnson (2002) which is believed that students with higher amount of test anxiety show much poor performance in their tests and evaluative situations rather than their peers with lower amount of test anxiety.

\section{CONCLUSION}

Regarding the results of this study the researcher concluded that both of formative and dynamic assessments of reading comprehension were effective on reducing of learners' test anxiety. Nowadays in Iran EFL context there is no sufficient emphasize on formative assessments and especially on dynamic assessments in language teaching programs. On the other hand, test anxiety is the common problematic phenomenon among Iranian EFL learners. So the researcher 
recommended English language teachers and learners to include these two types of assessment in their teaching and learning programs and activities. Also syllabus designers, curriculum developers and educational policy makers can use these findings to produce more effective syllabuses and curriculum programs for English learners. Focusing on positive role of formative and especially dynamic assessment on reduction of test anxiety can help teachers and learners to overcome this troublesome phenomenon in their learning language journey.

\section{APPENDIX. TEST ANXIETy QuESTIONNAIRE}

(Developed by Sarason, 1984 and revised by Benson \& Bandalos, 1992)

Below are statements that may or may not be relevant to you. Based on your personal experience, please indicate how frequently you experience these feelings or thoughts during testing situations. Please use the scale below and circle the number that best reflects how frequently you experience these responses.

Not at all typical of me $=1$

Only somewhat typical of me $=2$

Quite typical of me $=3$

Very typical of me $=4$

\begin{tabular}{|c|c|c|c|c|c|}
\hline $\mathrm{N}$ & Question & 1 & 2 & 3 & 4 \\
\hline 1 & I feel distressed and uneasy before a test. & & & & \\
\hline 2 & I feel jittery before tests. & & & & \\
\hline 3 & While taking a test, I feel tense. & & & & \\
\hline 4 & I am anxious about tests. & & & & \\
\hline 5 & I have uneasy feelings before an important test. & & & & \\
\hline 6 & The thought, "What happens if I fail this test?" goes through my mind during tests. & & & & \\
\hline 7 & During a difficult test, I worry whether I will pass it. & & & & \\
\hline 8 & While taking tests, I find myself thinking how much brighter other people are. & & & & \\
\hline 9 & After a test, I say to myself, "It's over and I did as well as I could". & & & & \\
\hline 10 & Thoughts of doing poorly interfere with my concentration during tests. & & & & \\
\hline 11 & During tests I think of how poorly I am doing. & & & & \\
\hline 12 & During tests I find myself thinking of things unrelated to the material being tested. & & & & \\
\hline 13 & I think about current events during a test. & & & & \\
\hline 14 & I have fantasies a few times during a test. & & & & \\
\hline 15 & While taking tests, I sometimes think about being somewhere else. & & & & \\
\hline 16 & During tests, I find I am distracted by thoughts of upcoming events. & & & & \\
\hline 17 & I feel the need to go to the toilet more often. & & & & \\
\hline 18 & I get a headache before a test. & & & & \\
\hline 19 & My mouth feels dry during a test. & & & & \\
\hline 20 & I sometimes find myself trembling before or during tests. & & & & \\
\hline
\end{tabular}

\section{REFERENCES}

[1] Bachman, L. F. (1990). Fundamental considerations in language testing. Oxford: Oxford University Press.

[2] Brown, H. D. (2004). Language assessment: Principles and classroom practices. White Plains, NY: Longman.

[3] Cassady, J. C., \& Johnson, R. E. (2002). Cognitive test anxiety and academic performance. Contemporary Educational Psychology, 27, 270-295.

[4] Chen, L. (2007). A study of the relationship between EFL reading anxiety and reading strategy use. (Unpublished master's thesis). National Taiwan University of Science and Technology, Taiwan.

[5] Ellis, R. (2003). Task-based language learning and teaching. Oxford: Oxford University Press.

[6] Feuerstein, R. (2002). The dynamic assessment of cognitive modifiability: The learning assessment device: Theory, instrument and techniques. Jerusalem: ICELP Press.

[7] Feuerstein, R., Rand, Y., \& Rynders, J. E. (1988). Don't accept me as I am. Helping retarded performers excel. New York: Plenum.

[8] Fulcher, G., \& Davidson, F. (2007). Language testing and assessment. An advanced resource book. London: Routledge.

[9] Grabe, W., \& Stoller, F. (2001). Reading for academic purposes: Guidelines for the ESL/EFL teacher. In M. Celce-Murcia (Eds.), Teaching English as a Second or Foreign Language (pp. 187-204). USA: Heinle \& Heinle.

[10] Guthke, J., Beckmann, J. F., \& Dobat, H. (1997). Dynamic testing problems, uses, trends and evidence of validity. Educational and Child Psychology, 14(4), 17-32.

[11] Hancocok, D. R. (2001). Effects of test anxiety and evaluative threat on students' achievement and motivation. The Journal of Educational Research, 95(5), 284-290.

[12] Hessamy, G., \& Ghaderi, E. (2014). The role of dynamic assessment in the vocabulary learning of Iranian EFL learners. Procedia, Social and Behavioral Sciences, 98, 645-652.

[13] Horwitz, M. B., Horwitz, E. K., \& Cope, J. (1986). Foreign Language Anxiety. The Modern Language Journal, 70, $125-132$.

[14] Kirschenbaum, R. J. (1998). Dynamic assessment and its use with underserved gifted and talented populations. Gifted Child Quarterly, 42(3), 140-147.

[15] Lantolf, J. P., \& Poehner, M. E. (2008). Dynamic assessment. Encyclopedia of Language and Education, 7, $273-284$.

[16] Lidz, C. S. (1991). Practitioner's guide to dynamic assessment. New York: Guilford.

[17] Na, Z. (2007). A study of high school students' English learning anxiety. Asian EFL Journal, 9(3), 22-34. 
[18] Poehner, M. E. (2008). Dynamic assessment: A Vygotskian approach to understanding and promoting L2 development. Berlin: Springer Science \& Business Media.

[19] Poehner, M. E., \& Lantolf, J. P. (2005). Dynamic assessment in the language classroom. Language Teaching Research, 9(3), 233-265.

[20] Saito, Y., Horwitz, E. K., \& Garza, T. J. (1999). Foreign language reading anxiety. Modern Language Journal, 83, $202-218$.

[21] Sarason, I. G. (1972). Personality: An objective approach ( $2^{\text {nd }}$ ed.). New York: Wiley.

[22] Sellers, V. D. (2000). Anxiety and reading comprehension in Spanish as a foreign language. Foreign Language Annals, 33(5), 512-520.

[23] Shomoossi, N., \& Kassaian, Z. (2009). Variation of test anxiety over listening and speaking test performance. Iranian Journal of Language Studies, 3(1), 65-78.

[24] Sternberg, R. J., \& Grigorenko, E. L. (2002). Dynamic testing: The nature and measurement of learning potential. Cambridge: Cambridge University Press.

[25] Torrance, H., \& Proyor, J. (1998). Investigating formative assessment: Teaching, learning, and assessment in the classroom. Buckingham: Open University Press.

[26] Tzuriel, D., \& Shamir, A. (2007). The effects of peer mediation with young children on children's cognitive modifiability. British Journal of Educational Psychology, 77(1), 143-165.

[27] Zeidner, M. (1998). Test anxiety: The state of art. New York, USA: Plenum Press.

Seyyed Hossein Sanaeifar has MA of TEFL. He is Ph.D. candidate of TEFL at Islamic Azad University, Qaemshahr, Iran. He has been teaching English language for about 7 years. He published some articles and presented some articles in national conferences in Iran. His areas of interest are reading comprehension, vocabulary and idiom learning, and language testing.

Fatemeh Nafarzadeh Nafari has MA of TEFL. She is Ph.D. candidate of TEFL at Islamic Azad University, Qaemshahr, Iran. She has been teaching English language for about 9 years. She published some articles and presented some articles in national and international conferences. Her areas of interest are teacher education, and language testing. 